\title{
Forest Edge Regrowth Typologies in Southern Sweden-Relationship to Environmental Characteristics and Implications for Management
}

\author{
Björn Wiström (D) ${ }^{1}$ Anders Busse Nielsen ${ }^{1,2}$
}

Received: 16 July 2015 / Accepted: 20 March 2017 / Published online: 10 April 2017

(C) Springer Science+Business Media New York 2017

\begin{abstract}
After two major storms, the Swedish Transport Administration was granted permission in 2008 to expand the railroad corridor from 10 to $20 \mathrm{~m}$ from the rail banks, and to clear the forest edges in the expanded area. In order to evaluate the possibilities for managers to promote and control the species composition of the woody regrowth so that a forest edge with a graded profile develops over time, this study mapped the woody regrowth and environmental variables at 78 random sites along the $610-\mathrm{km}$ railroad between Stockholm and Malmö four growing seasons after the clearing was implemented. Through different clustering approaches, dominant tree species to be controlled and future building block species for management were identified. Using multivariate regression trees, the most decisive environmental variables were identified and used to develop a regrowth typology and to calculate species indicator values. Five regrowth types and ten indicator species were identified along the environmental gradients of soil moisture, soil fertility, and altitude. Six tree species dominated the regrowth across the regrowth types, but clustering showed that if these were controlled by selective thinning, lower tree and shrub species were generally present so they could form the "building blocks" for development of a
\end{abstract}

Björn Wiström

bjorn.wistrom@slu.se

1 Faculty of Landscape Planning, Horticulture and Agricultural Science, Department of Landscape Architecture, Planning and Management, Swedish University of Agricultural Sciences, Box 66, Alnarp 23053, Sweden

2 Faculty of Science, Department of Geosciences and Natural Resource Management, Section for Landscape Architecture and Planning, University of Copenhagen, Rolighedsvej 23, Frederiksberg C 1958, Denmark graded edge. We concluded that selective thinning targeted at controlling a few dominant tree species, here named Functional Species Control, is a simple and easily implemented management concept to promote a wide range of suitable species, because it does not require field staff with specialist taxonomic knowledge.

Keywords Right-of-way $\cdot$ Forest edge $\cdot$ Railroad $\cdot$ Succession $\cdot$ Management

\section{Introduction}

With ongoing climate change (IPCC 2013), roads, railroads, powerlines, and houses situated in forested landscapes run an increasing risk of storm damage by wind-felled trees (e.g., Fankhauser et al. 1999; Lindner et al. 2010; Leviäkangas and Michaelides 2014). Therefore the development of more storm-resistant and resilient forest edges is of great relevance in securing and maintaining functional infrastructure.

After two major storms with record winds in 2005 and 2007, the Swedish Transport Administration received legal permission in 2008 to expand the railroad corridor from 10 to $20 \mathrm{~m}$ from the rail banks, and to clear the forest edges in the expanded area. The old management corridor $(0-10 \mathrm{~m}$ distance from rail banks) is to be kept clear of woody vegetation to support visibility along the railway. In the new management corridor (10-20 m from rail banks, hereafter called NMC), regrowth of woody vegetation is allowed until it reaches a height where it poses a risk of damage to railway infrastructure in the event of storm felling. Therefore, the long-term management goal for NMC is to successively manage the woody regrowth, i.e., spontaneously 
established trees and shrubs, so that it supports biodiversity and ecosystem functions, in parallel with infrastructure security. A graded edge profile with low vegetation at the periphery and increasingly higher shrubs and trees toward the interior is considered desirable to achieve this. Compared with abrupt forest edges dominated by tree species, graded edges provide valuable wildlife habitats and a wider range of ecosystem functions and services (Buckley et al. 1997; Fry and Sarlöv-Herlin 1997; Wuyts et al. 2009; Ruck et al. 2012). They also keep tall trees at a distance from the railway and its infrastructure (Rühle 1995; Rydberg and Falck 2000; Ballard et al. 2007; Wiström et al. 2015).

Edge vegetation along railroads, roads, and other infrastructure-so-called right-of-way (ROW) vegetation-constitutes an important ecotone habitat and linear corridor for dispersal/migration in the landscape (Berg et al. 2013; Morelli et al. 2014; Wagner et al. 2014). However, knowledge about how woody vegetation regenerates following clearing is essential for management efforts to promote and control the species composition toward the development of a graded edge.

Community assembly is complex and related to both direct and indirect environmental gradients (e.g., Austin et al. 2006; Borcard et al. 2011). Nevertheless, experiences from forestry, including nature-based forestry, and conservation management indicate that classification of woody species composition according to the relationship of key species to decisive environmental characteristics can inform the development of long-term management goals and approaches (Knight et al. 2006; Larsen and Nielsen 2007; Cáceres and Legendre 2009). However, studies on plant regrowth after initial clearing of forest edges and its classification are rare, and tend to focus on single crop trees in strip shelterwood systems as a forestry practice in central Europe, where stands are regenerated successively in time and space (e.g., Wagner 1912; Henriksen 1988). A few studies conducted in the nemoral vegetation zone have also addressed initial clearing of forest edges as a conservation practice (e.g., Buckley et al. 1997; Non and de Vries 2013).

Nowak and Ballard (2005) emphasize the need to target problem species in order to enable an integrated vegetation management approach to ROW environments. Nonselective clearing generally encourages regrowth of fastgrowing pioneer broad-leaved species (e.g., Luken et al. 1991; Rydberg 2000). These species specialize in rapidly capturing the resources released after disturbance (Grime 2001), through a high capacity for sprouting from stool and roots, combined with great abundance of wind-dispersed seeds. As these pioneer species lead to rapid growth in height and homogeneous structures, the ROW literature advocates selective thinning methods, despite the higher initial management costs (e.g., Mercier et al. 2001; Clarke and White 2008).
Forestry practitioners and researchers in related fields have amassed extensive experience of thinning regrowth following clearcutting (so-called pre-commercial thinning). Within Swedish forestry, such thinning activities focus on favoring Pinus sylvestris, Picea abies, and other commercial species by controlling pioneer broad-leaved species and subordinate species that are undesirable for commercial forestry. As the focus is on "thinning for" the commercial species, irrespective of the species competing with them, this kind of pre-commercial thinning does not require field staff with specialist taxonomic knowledge.

Existing ROW environment studies have mainly been conducted in North America and focus on powerlines, with repeated clearing and/or chemical control (e.g., Dreyer and Niering 1986; Luken et al. 1991; Hill et al. 1995; Mercier et al. 2001; Yahner et al. 2008; Wagner et al. 2014). However, Clarke and White (2008), Berg et al. (2013), and Komonen et al. (2013), for example, have carried out ROW studies in other parts of the world. Forest edge studies in the hemi-boreal zone have mainly focused on edge effects in relation to large clear-cuts (Marozas et al. 2005) or in an urban context (e.g., Hamberg et al. 2008; Hamberg et al. 2010), but rarely over large and complex environmental gradients.

The present study examined woody regrowth following initial clearing of a NMC along the main railroad transect from Malmö to Stockholm in Sweden. The railroad spans $610 \mathrm{~km}$ in length and includes large complex environmental gradients. The overall aim was to assess management possibilities to promote species richness and infrastructure security by control of the species composition and successive development of a graded forest edge profile. Specific objectives were to:

(A) Classify the regrowth with respect to woody species composition

(B) Identify the most influential environmental gradients (variables) for classifying and predicting the species composition of the woody regrowth

(C) Identify woody "indicator" species for the different regrowth types

(D) Compare vegetation structure between regrowth types

\section{Method}

\section{Study Area}

Södra stambanan (Southern main line, hereafter SML) is the main railroad track in southern Sweden. It connects Malmö $(55.609814 \mathrm{~N} ; 13.00115 \mathrm{E})$ the third largest city, with Stockholm (59.330497N; 18.05603E), the capital. Applying a $1000 \mathrm{~m}$ buffer around SML in analysis of national GIS 
data (ㄷ) Lantmäteriet i2014/00764, @) Naturvårdsverket, i2014/764; @ SMHI i2014/00764) shows that the altitude of the railroad ranges from 0 to $336 \mathrm{~m}$ above sea level (mean \pm standard deviation $(\mathrm{SD}) 105.15 \pm 78.30 \mathrm{~m}$ ). Mean annual precipitation ranges from approximately 600 to $900 \mathrm{~mm}$ and the cumulative temperature sum per year ranges between 1272 and $1789^{\circ} \mathrm{C}\left(\right.$ mean \pm SD $\left.1494.88 \pm 131.78^{\circ} \mathrm{C}\right)$. This gives an overall slightly humid climate. The positive product of mean precipitation, after subtraction of evapotranspiration during the vegetation period, ranges between 33 and $156 \mathrm{~mm}$ (mean \pm SD $91.71 \pm 34.15 \mathrm{~mm}$ ), with an overall decreasing trend toward the east. The soil type varies widely and includes peat soils, glacial tills, and sedimentary soils ranging from clayish to coarse sandy and gravel types. The variations in soil and macroclimate are reflected in differing landscape composition along the railroad, ranging from plains with intensive agriculture and urbanization (as little as 6\% forest cover), through mosaics of small-scale agriculture and forest patches, to forest landscapes (as much as $94 \%$ forest cover). The dominant land cover is forest, with a total cover of $45 \%$ divided between conifer (26\%), deciduous (8\%), mixed (4\%), and clearcut/regenerating forest (7\%).

After severe problems with wind-felled trees and related disruptions to railroad traffic, the SML management corridor was one of the first in Sweden to be expanded from 10 to $20 \mathrm{~m}$ on both sides of the track, by clearing forest edge vegetation in the NMC.

\section{Field Inventories}

A field inventory of SML was conducted in autumn 2011, four growing seasons after clearance, at 78 random sites located on the forest edge as defined by the National Inventory of Landscapes in Sweden (Gallegos Torell 2011) (Fig. 1). At each site, a plot of $35 \times 20 \mathrm{~m}$ was established so that one half covered the NMC and the other half covered the bordering forest stand (hereafter denoted STAND), resulting in a NMC and STAND zone each measuring $10 \times$ $35 \mathrm{~m}$ (Fig. 2). The border between STAND and NMC was set as the average outer line of tree trunks, in accordance with the NILS field protocol (Gallegos Torell 2011).

Within the plot, four transects were established $10 \mathrm{~m}$ apart, perpendicular to the railroad (Fig. 2). Along each transect, five circular subplots (1-5) were set so that the first two plots were located in the NMC (the first had its center 9 $\mathrm{m}$ outside the forest stand border, the second its center 4.5 $\mathrm{m}$ outside the stand border), the third was located with its center at the border between the STAND and NMC zones, and subplots 4 and 5 were located in the forest STAND (4.5 and $9 \mathrm{~m}$ inside the forest stand, respectively), resulting in a total of 20 subplots per site (Fig. 2). In each subplot, woody vegetation was sampled at two levels: (a) within a $0.5 \mathrm{~m}$ radius, species and number of woody plants $<1 \mathrm{~m}$ in height were counted; (b) within a $1 \mathrm{~m}$ radius, species, height, and number of woody plants $\geq 1$ to $\leq 5 \mathrm{~m}$ in height were recorded. Furthermore, in (b) the mean height of the field layer $(10 \mathrm{~cm}$ intervals) was measured and field layer cover $(10 \%$ intervals) was estimated. For the STAND zone, a third level (c) was added where within a radius of $2 \mathrm{~m}$, circumference at breast height $(\mathrm{CBH})$ was measured for all specimens $>5$ $\mathrm{m}$ in height.

Based on the field data, two woody species matrices were developed at plot level. (i) A species matrix for the NMC was established using subplots 1-3 from each transect (i.e., a total of 12 subplots) with species represented as counts of stems (sampling level b), but with specimens $<1 \mathrm{~m}$ (sampling level a) restricted to one count per species and subplot to downgrade the importance of small seedlings with little probability of full survival for all counts. (ii) A species matrix for the STAND was also established, where species were represented by the $\mathrm{CBH}$ for subplots 3-5 (sampling level c).

\section{Environmental Characteristics}

Using the species data derived from the field work described above, Wiström and Nielsen (2016) applied ordinations to identify ten environmental variables at different scales that are significant for woody regrowth in the NMC and the bordering forest STAND. These variables represent aspects of soil conditions, climate, vegetation, and landscape structures as summarized below and in Table 1 .

\section{Field layer type}

Field layer type in the STAND zone was classified using the standard classes and definitions from the Swedish Forestry site classification system (Hägglund and Lundmark 2010). The standard circular sampling shape $\left(\operatorname{area}=314 \mathrm{~m}^{2}\right)$ was adjusted to fit within the STAND zone $\left(\operatorname{area}=350 \mathrm{~m}^{2}\right.$ ).

\section{Soil moisture}

Soil moisture classes were determined using standard classes and definitions from the Swedish Forestry site classification system (Lundin et al. 2002; Hägglund and Lundmark 2007a, b, 2010). Intermediate classes were added in accordance with, e.g., Ellenberg (1988).

\section{Canopy cover}

The overall canopy cover in the STAND zone was visually estimated in intervals of $5 \%$. 


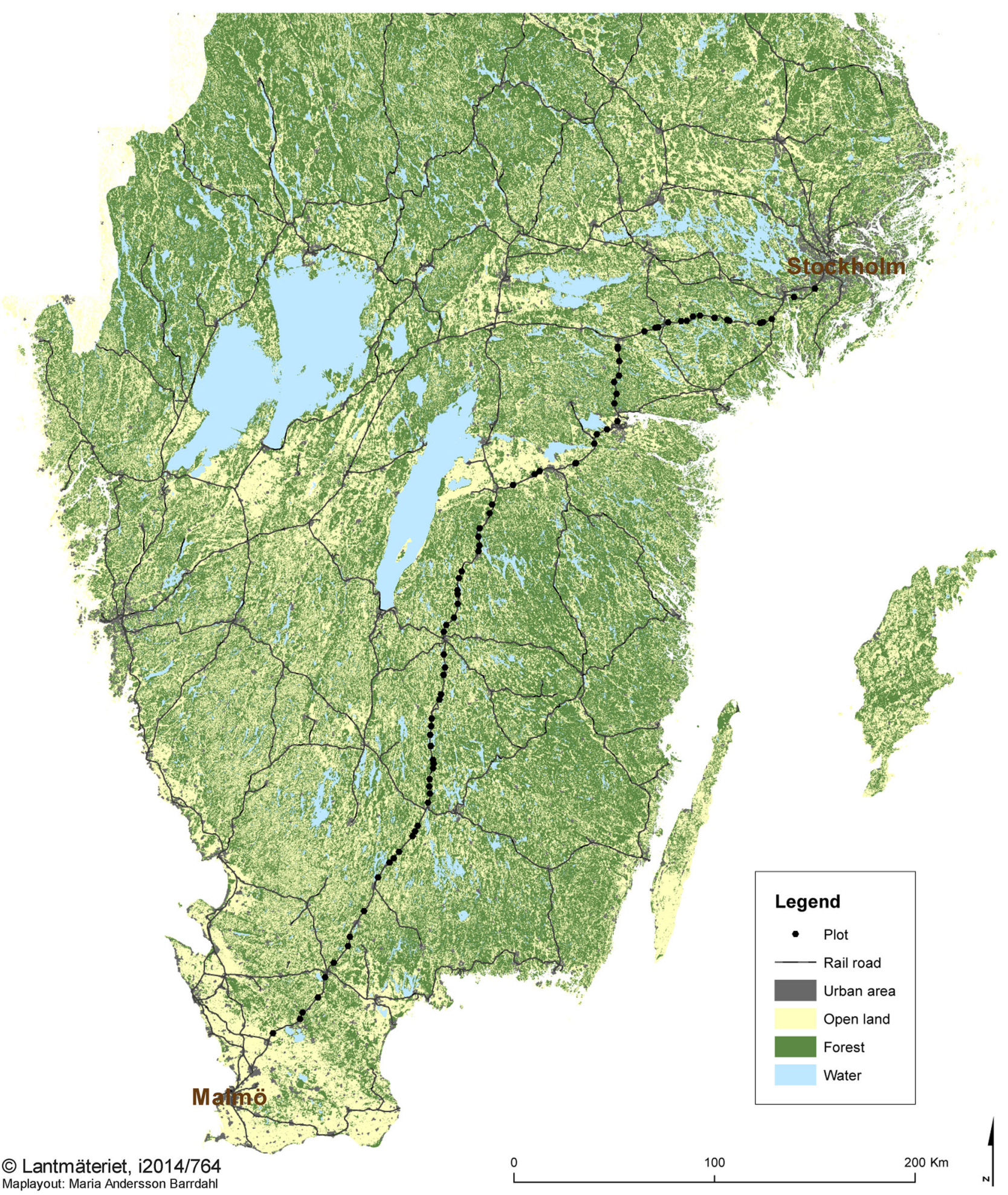

Fig. 1 Location of the 78 study sites along SML in Sweden between Malmö in the south and Stockholm in the north

\section{Dripline}

The distance from the crown dripline to the border between the STAND and NMC zone was measured for each transect with a measuring tape and pooled to an average of the four transects.

\section{$\mathrm{CBH}-\mathrm{CV}$}

Using the $\mathrm{CBH}$ measurements, the coefficient of variance was calculated. 
Fig. 2 Schematic diagram of the sampling set-up used for each site (not to scale)

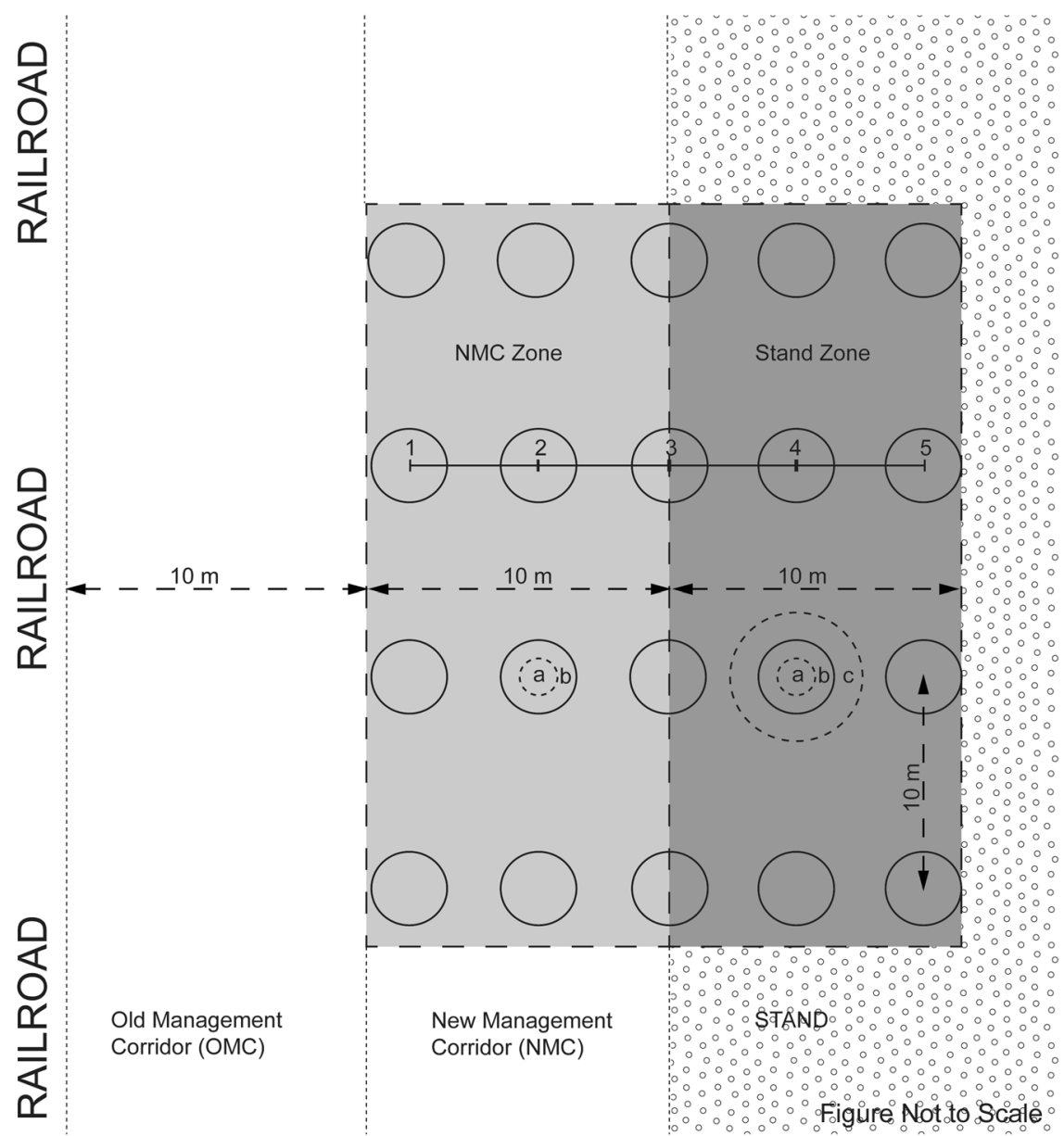

\section{Humidity and altitude}

Digital maps were used to determine the humidity (Temperatursummor och humiditet, (C) SMHI i2014/00764, polygon based) and altitude (GSD-Höjddata, grid 50+, (C) Lantmäteriet i2014/00764, resolution $50 \mathrm{~m}$, and standard error $1 \mathrm{~m}$ ) for each site.

\section{AgeStDev}

The SLU Forest Map (kNN-Sverige 2010) on stand age, which is produced by a k-nearest neighbors $(\mathrm{kNN})$ method (see Reese et al. 2003 for details), was used to estimate the age structure of forests within a $1000 \mathrm{~m}$ radius of the sites and calculate the SD of stand age within this area.

\section{SHAPE_MN and TECI}

ArcGIS 10.1 (ESRI, Redlands, CA, USA) was used to extract raster files and FRAGSTAT 4.1 (McGarigal et al. 2012) to calculate the landscape metrics from the raster files. The base data used were the Swedish Land Cover Data (SMD—Svenska Marktäckedata @ Naturvårdsverket i2014/
00764) with standard resolution (grain size) of $25 \mathrm{~m}$. No background or matrix landscape type was specified, since in the present study areas with a variety of landscape matrices were sampled. Furthermore, a "landscape border" was defined around each landscape analyzed, by letting FRAGSTAT know the landscape types bordering outside the specified radius of $1000 \mathrm{~m}$ (for definitions and concepts, see McGarigal et al. 2012). Patches in the calculations were defined using the eight-neighbor rule, to guarantee that linear diagonal elements were not subdivided into multiple patches (Turner et al. 2001). The raster grids were reclassified into three clearly non-forested classes (urban built areas, agricultural fields, and water), one semi-open class holding the potential of some woody vegetation (e.g., urban green areas, grazing areas, and riparian zones) and forested areas (deciduous, mixed, conifers, and regenerating forest sites). This gave eight different landscape types, for which an edge contrast matrix was developed based on the theoretical assumption that the contrast between forest and human land use of agricultural fields and built-up areas is high, the contrast between semi-open and other types is intermediate, and the contrast between different forest types is low. 
Table 1 Environmental variables used in the analysis

\begin{tabular}{|c|c|}
\hline Variable & Description \\
\hline Field layer type & $\begin{array}{l}\text { Nine classes (Ordinal). Classes are determined on the accumulated coverage of different } \\
\text { indicator species for site fertility, where class (a) is the poorest and (i) the richest site } \\
\text { class; (a) horsetail-sedge type, (b) crowberry-heather type, (c) lingonberry type, (d) } \\
\text { bilberry type, (e) narrow-leaved grass type, (f) broad-leaved grass type, (g) without field } \\
\text { layer, (h) low herb type, (i) tall herb type. It is a robust indicator of the site fertility as an } \\
\text { important soil variable }\end{array}$ \\
\hline Soil moisture & $\begin{array}{l}\text { Four classes of soil moisture were extended to eight (Ordinal) in accordance with } \\
\text { Ellenberg (1988), with estimates based on the geophysiographical conditions and } \\
\text { reflecting the average distance from the watertable during the vegetation period. (a) dry } \\
\text { (torrt), (b) slightly dry, (c) damp (friskt), (d) slightly moist, (e) moist (fuktigt), (f) slightly } \\
\text { wet, (g) wet (blött), (h) very wet. Soil fertility and soil moisture are the two classical soil } \\
\text { variables in vegetation ecology and forestry }\end{array}$ \\
\hline Canopy Cover & $\begin{array}{l}\text { Estimated canopy cover in the } 35 \times 10 \mathrm{~m} \text { STAND zone of site plots. Reflects horizontal } \\
\text { aspects of the stand }\end{array}$ \\
\hline Dripline & $\begin{array}{l}\text { Average canopy dripline of the trees forming the border between the NMC and STAND } \\
\text { zone of site plots. Indicates aspects of the old forest edge profile before cutting }\end{array}$ \\
\hline CBH_CV & $\begin{array}{l}\text { Coefficient of variance for } \mathrm{CBH} \text { of specimens in the STAND zone of site plots. Reflects } \\
\text { canopy stratification and as such the vertical aspects of the vegetation structure }\end{array}$ \\
\hline Humidity & $\begin{array}{l}\text { Product of mean precipitation with evapotranspiration during the growing season } \\
\text { subtracted. Defines the overall water ability at landscape scale }\end{array}$ \\
\hline Altitude & $\begin{array}{l}\text { Altitude (measured as meters above sea level) is a classical complex gradient in } \\
\text { vegetation ecology studies }\end{array}$ \\
\hline AgeStDev & $\begin{array}{l}\text { Standard deviation of the forest age in the surrounding landscape ( } 1000 \mathrm{~m} \text { buffer) based } \\
\text { on the SLU Forest Map. Indicates the continuity of the surrounding landscape }\end{array}$ \\
\hline TECI & Total edge contrast index. Gives a measure of the contrast of the edges in the landscape \\
\hline SHAPE_MN & Mean shape index. Gives a measure of the shape of the edges in the landscape \\
\hline
\end{tabular}

In the present study, these ten environmental variables identified by Wiström and Nielsen (2016) were used as explanatory measures in multivariate analyses of the species composition, vegetation structures, and role of individual species in the NMC and STAND that jointly constitutes the forest edge along the railroad. The analyses had an applied focus on assessing the possibilities for management to achieve a species composition that supports successive development of a species-rich graded forest edge.

\section{Overview of Analytical Approach}

In relation to the objectives of the study, the following analytical steps were applied in sequence:

(A) Hierarchical clustering methods were combined with graphical exploration tools to classify the regrowth with respect to woody species composition and assessment of possibilities to promote a graded edge profile by controlling the species composition.

(B) Multivariate regression trees were applied to identify the most influential environmental variables for classifying and predicting the species composition of the woody regrowth.

(C) Indicator values were then applied in the multivariate regression tree and compared with results from the earlier clustering to provide a robust basis for identification of woody "indicator" species for the different regrowth types.

(D) Vegetation structure for the different regrowth types identified in the multivariate regression tree was compared by use of univariate mixed modeling, testing for differences in relation to five vegetation structure variables.

\section{Data Analysis}

All multivariate analysis was performed in $\mathrm{R}$ (R Core Team 2014) using the additional packages vegan (Oksanen et al. 2013), cluster (Maechler et al. 2014), labdsv (Roberts 2013), mvpart (Therneau et al. 2013), and MVPARTwrap (Ouellette and Legendre 2013), with syntax and analytical approaches adapted from Borcard et al. (2011). Species matrices for NMC and STAND were analyzed separately. The different analyses are described in detail below.

\section{Hierarchical Clustering}

For both species matrices, four of the most common hierarchical clustering approaches were applied using Chordtransformed data (which removes the total abundance per 
site, i.e., the response of the species to the total productivity of the sites) and Euclidian distances: (i) Single linkage agglomerative clustering, which is good for detecting gradients; (ii) complete linkage agglomerative clustering, which is efficient in finding distinct groups; (iii) average agglomerative clustering using the unweighted pair group method with arithmetic mean (UPGMA), which can be seen as intermediate to the above methods; and (iv) Ward's minimum variance clustering, which defines groups so that the within-group sum of squares is minimized, often giving tightly bound clusters, although these may not always reflect the underlying data set (El-Hamdouchi and Willett 1989; Borcard et al. 2011).

To compare the different clusterings, the cophenetic correlation coefficient between the original dissimilarity matrix and the cophenetic matrix from the clustering was calculated. They were also plotted together in Shepard-like diagrams (Legendre and Legendre 1998) with a lowess smoothing function. Based on this, the most appropriate clustering was selected for further analysis.

To assess the optimal number of clusters according to silhouette widths, the Rousseeuw quality index was used, together with fusion plots where number of clusters was plotted against node height. Using the selected number of clusters, the amount of misclassification in silhouette widths was assessed through silhouette plotting (Rousseeuw 1987).

\section{Hierarchical Clustering in Relation to Species}

To visualize the species and their abundance in relation to the clustering and dendrogram, the tabasco function with "log" as scale range in vegan, which displays compact community tables with an interface to the heatmap function, was applied. This gave a color image of the species data abundance ordered in relation to the clustering.

The output of the clustering and tabasco heatmap was then examined for tree species dominating the different clusters for the NMC and STAND zones. Six tree species clearly dominated in the different clusters. An "idealized management data set" was then created where these six dominant tree species with a high probability of driving regrowth toward an abrupt edge profile and homogeneous structure were removed from the NMC data set (as if they had been cut by selective thinning). Acknowledging that the six species will regenerate generatively and/or vegetatively, this idealized data set enabled analyses of the regrowth in relation to a management scenario. The clustering was then re-run to determine and assess the relative abundance of remaining species, i.e., the idealized management data set enabled assessment of the presence and abundance of smaller tree and shrub species in the different clusters that, if promoted by management, could form the "building blocks" for development of graded forest edges. Furthermore, the idealized management data set enabled the identification of other minority tree species that have to be addressed in long-term management. When sites had to be filled with a pseudospecies to enable the analysis to be run, this indicated a lack of other species than the six dominant tree species.

\section{Regression Trees}

Multivariate regression trees (hereafter shortened to "regression trees") were used to relate the regrowth clusters to the environmental variables and identify the variables that drive the woody regrowth into different species compositions (De'ath and Fabricius 2000; De'ath 2002). Significant species for the division of groups and the final grouping were identified by combining the regression trees with a Chord pre-transformation and the species indicator values developed by Dufrene and Legendre (1997).

\section{Vegetation Structure and Regrowth Types}

Species are the building blocks of the forest edges. However, it is not only the species composition, but also the overall structure of the edges and its relation to regrowth types, that are of interest. One important aspect is to compare differences in vegetation structure between the regression tree groups, in order to enable in-depth analysis without directly including species assembly. Therefore, some key responses relating to the forest edge structure and edge effect were modeled using the placement of the five different subplots perpendicular to the forest edge. This was done using mixed general linear models in SAS 9.3 Proc Mixed procedure. The structural aspects, i.e., responses, for the different models were number of stems, maximum height of stems, number of seedlings (i.e., height $<1 \mathrm{~m}$ ), average field layer coverage, and average field layer height. These were calculated as the mean value of the transects for each subplot level at the sites. Square root transformation was used on the response when needed to fulfil the assumptions of the model, which were checked through inspection of diagnostic plots of the conditional residuals. For each response, a model was fitted with the regression tree classification (class variable with five levels) and subplot (class variable with five levels), and their interactions as explanatory variables. Regression tree classification was nested under "Site" to avoid pseudoreplication. "Site" was modeled as a random variable. To investigate and handle the probable dependence between subplots, each model was compared concerning model fit with Akaike information criterion (AIC) using either a standard variance components structure (VC) or a first-order autoregressive structure (AR1) for the covariance structure for random effects. To analyze interaction effects, the SLICE 
statement was used in a partitioned analysis of the least squares means, which is described as an analysis of simple effects by Winer (1971). As such, the SLICE statement looks at the predicted values across subplot for different levels of classification, and vice versa.

\section{Results}

\section{Hierarchical Clustering}

For the NMC, the cophenetic correlation coefficient was highest for the UPGMA method (0.820), followed by complete linkage (0.701), Ward's clustering (0.565), and single linkage (0.489). For STAND composition too, UPGMA had the highest cophenetic correlation coefficient (0.902), followed by complete linkage (0.849), single linkage clustering (0.736), and Ward's clustering (0.575). Therefore, UPGMA was selected as the clustering method for species composition in both NMC and STAND.

The optimal number of clusters based on Rousseeuw quality index for the UPGMA clustering was nine for the NMC and seven for the STAND zone. This amount of clusters resulted in two clear misclassifications of site for the NMC clustering, based on silhouette width plotting, and none for the STAND classification.

\section{Hierarchical Clustering in Relation to Species}

On combining the species abundance data with the clusters obtained in the heatmaps (Figs 3,4), it was evident that Populus tremula, Betula pendula, and Betula pubescens dominated the NMC, that they were partly overtaken by Pinus sylvestris and Picea abies in the STAND zone, and that Alnus glutinosa, when present, was clearly dominant for those clusters. These six dominant tree species, which have a high probability of driving the regrowth toward an abrupt edge profile, were therefore excluded from the idealized management data set for the NMC.

In the idealized management data set, the number of clear misclassifications did not increase. However, the ideal number of clusters increased to 12 . Only 2 out of the 78 sites needed auxiliary pseudospecies to enable re-run of the clustering. The combination of species and clustering in the heatmap (Fig. 5) showed that the abundance of Corylus avellana, Frangula alnus, Salix ciniera, and Sorbus aucuparia makes them potential building block species for the development of a graded forest edge profile. Quercus robur and Salix caprea were the most common minority tree species in the idealized management clustering.

\section{Regression Trees and Indicator Species}

The most parsimonious regression tree for NMC was obtained with five groups, where soil moisture, field layer type, and altitude were the environmental variables selected (see Fig. 6). The most decisive gradient was soil moisture, which divided the trees into one moist-wet and one damp-dry branch in the regression tree. The next branching was between fertile and poorer field layer types, which reflect the overall productivity of the site. Within the richer-drier sites, altitude caused another branching of the re-growth types. Overall, the same species detected in the heatmaps occurred as indicator value species for the splitting of branches and for the final groups, but some new species also occurred. A characteristic in common for these new species, which comprised Acer platanoides, Juniperus communis, Fraxinus excelsior, Prunus avium, Prunus padus, and Sambucus racemosa, was that they only occurred at a few locations but, when present, were strongly related to the specific environmental characteristics guiding the regression tree process.

\section{Vegetation Structure and Regrowth Types}

For all five models, AIC was lower when an AR1 structure, rather than a VC structure, was used as the covariance structure for random effects, signifying spatial dependence between the subplot levels. All results reported are therefore based on modeling including the AR1 structure. The results for the tests concerning the five models are presented in Table 3 and their relations/interactions are illustrated in Fig. 7. Overall, the pattern was for a strong influence of subplot level and classification (cluster), with some interactions between the two main effects. However, since the interaction effects were generally smaller relative to the main effects when comparing the $F$-values, these interactions could be seen as less important. This reasoning is strengthened by the SLICE effects size showing clear differences between effects, meaning that there was a strong overall edge effect pattern for the sites, but its magnitude was related to the clustering groups.

\section{Discussion}

\section{Regrowth Types}

In ecology, community and continuum theories are still being debated (Peper et al. 2011), as are methods of testing these theories (Jansen and Oksanen 2013). Clustering is not a statistical test but rather a heuristic procedure, so interpretation of the present results should take this into account. While distinct discontinuous clusters of species composition were identified in the present study, none 
Fig. 3 Heatmap of the UPGMA clustering for the NMC.

Grouping and dendrogram at the top, abbreviated species to the right (see Table 2), and site numbers at the bottom. The darkest color (red) indicates the highest abundance and the brightest (yellow) the lowest form of species as small shrub, large shrub, shrub tree/small tree, and tree is graphically illustrated to the left abundance. General growth

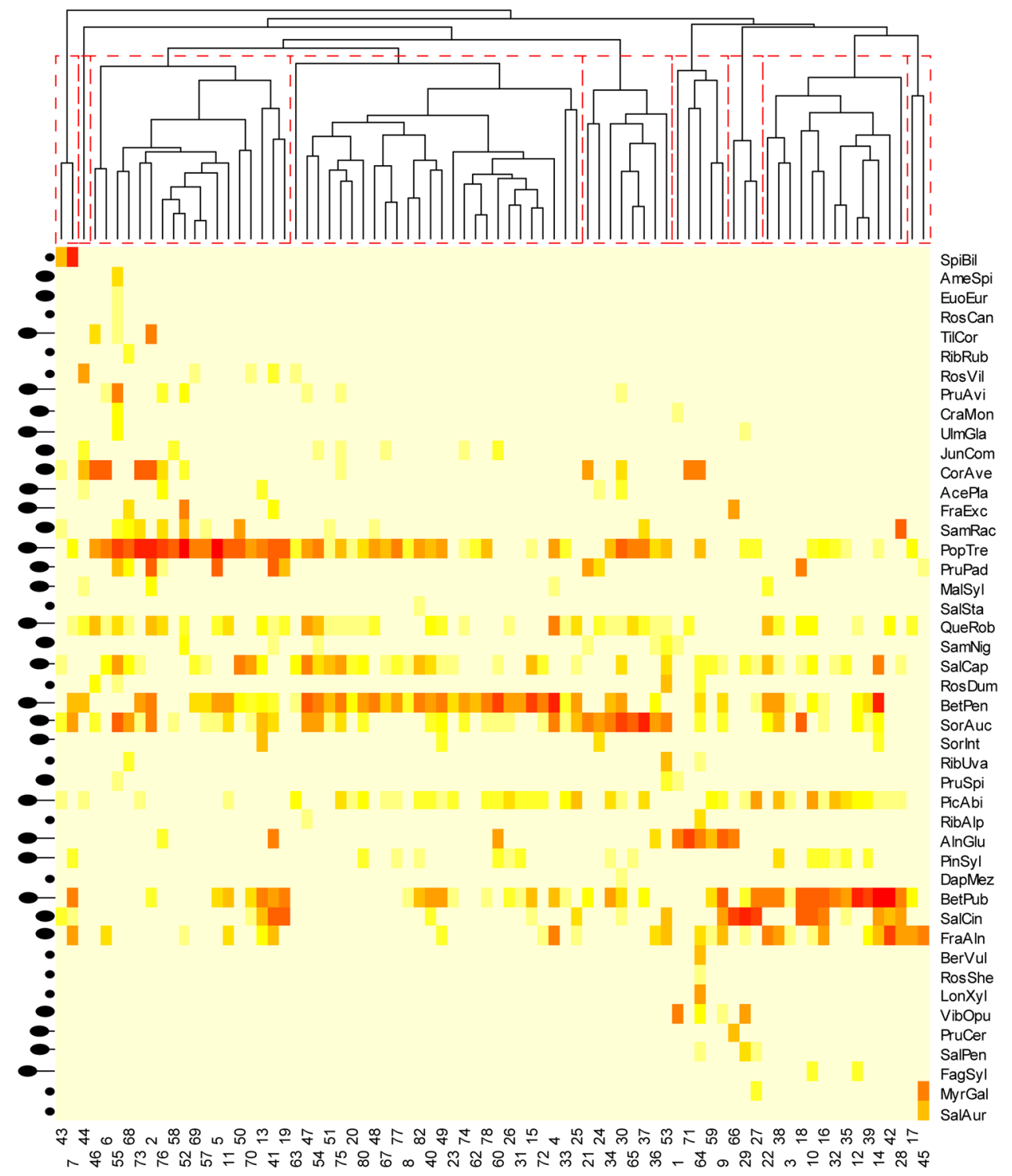

of the complete or single linkage clustering methods outperformed the others. This illustrates that the regrowth types identified overlapped, an effect which seems to have been enforced through the succession process. Therefore, clustering in relation to decisive environmental variables, as performed in the regression tree analysis, appears to be a valid compromise to classify postclearance regrowth with respect to different woody species composition.

As with almost all multivariate biological field data, the amount of explained variance was rather low for the regression tree classification. Thus, the usefulness of the regression tree approach has to be related to intended application. From a practical point of view, the regression tree developed here is useful since it can be used as a prediction tool with defined cut-off points that can be accompanied by indicator species values for field determination, since they are "interpretable" as probabilities (Cáceres and Legendre 2009). However, the early stage of succession studied here (four growth seasons after clearing of the NMC) limits the explanatory power, simply because more complex patterns will drive the development of the woody vegetation in the NMC during later successional stages. In particular, over time biotic variables related to vegetation structure at site and landscape level, such as propagule spread and browsing dynamics, are likely to become more influential (Grashof-Bokdam 1997; Wirth et al. 2008; Götzenberger et al. 2012).

\section{Decisive Environmental Gradients for Woody Regrowth Composition}

The finding that soil moisture and site productivity (as indicated by field layer type) are strong determinants of 
Fig. 4 Heatmap of the UPGMA clustering for the STAND zone. Grouping and dendrogram at the top, abbreviated species to the right (see Table 2), and site numbers at the bottom. The darkest color (red) indicates the highest abundance and the brightest (yellow) the lowest abundance. General growth form of species as small shrub, large shrub, shrub tree/small tree, and tree is graphically illustrated to the left

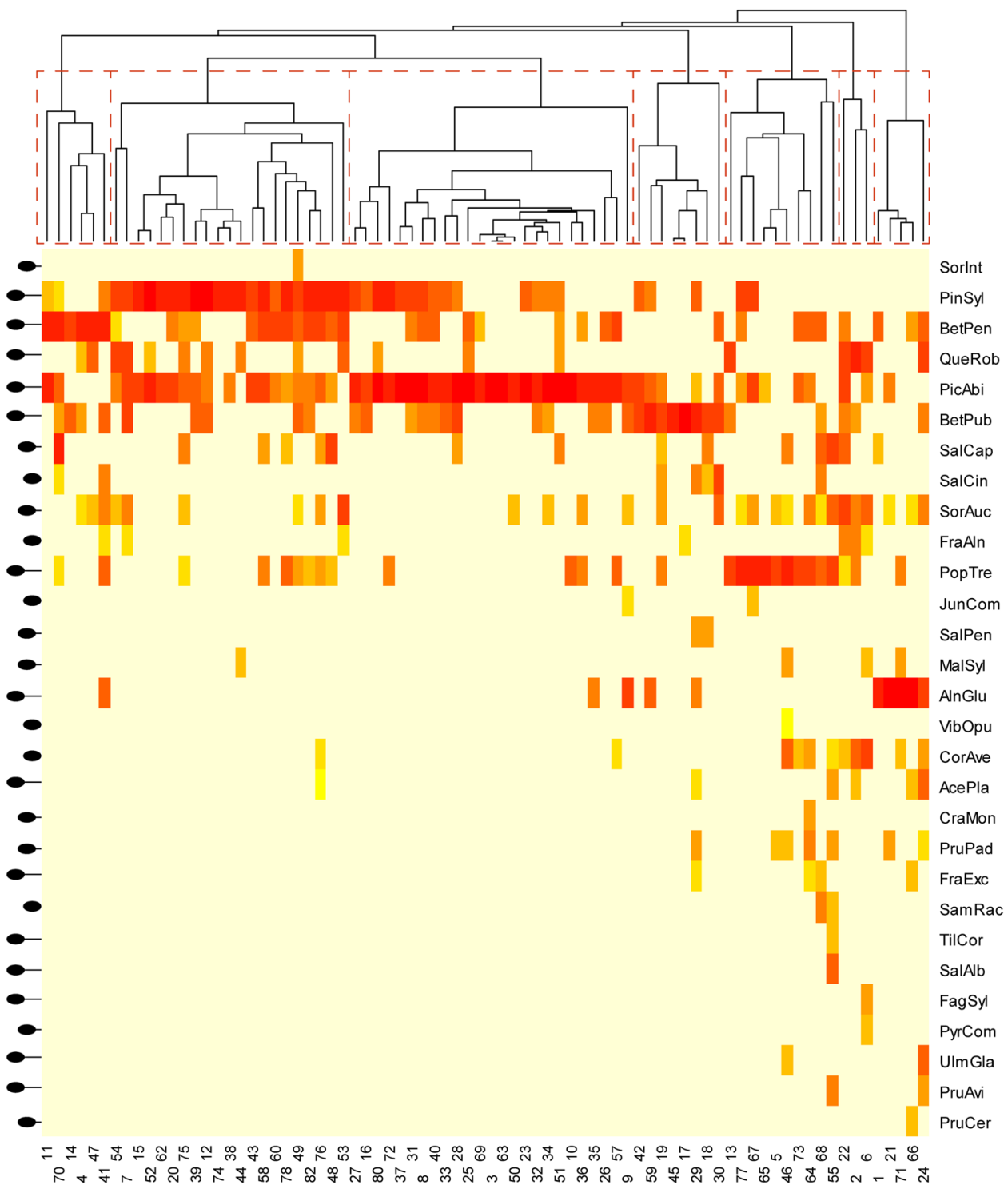

species composition confirms classic vegetation ecology (e.g., Ellenberg 1988). However, studies reporting this for forest edges are rare and concentrated to Central Europe (e.g., Coch 1995 and references within). The soil fertility branching in the regression tree has clear links to the phytosociological classification in Sweden, with the two subsets "Hedserien" (heath series; nutrient-poorer sites) and "Ängserien" (meadow series; nutrient-richer sites) (Påhlsson 1998). The further branching based on altitude is also in line with classical ecological work such as that by Whittaker (1956), where associated changes in temperature and precipitation affect resource availability and the stress regime for species. However, it should be noted that altitude is a complex gradient encompassing many basic gradients such as temperature and precipitation.

\section{Edge Structure}

There is great deviation in reported edge effects (Murcia 1995; Ries et al. 2004), but many studies have concluded that the structural changes in the edge are often quite short, seldom exceeding $20 \mathrm{~m}$ (Ranney et al. 1981; Didham and Lawton 1999; Šálek et al. 2013). Thus the main trends concerning edge structures should be obtained by examining a range of $20 \mathrm{~m}$, as was done in this study. Edge structure affects the edge effects (Didham and Lawton 1999; Hamberg et al. 2009), with the succession of the edge toward a more closed structure decreasing the distance of gradient turnover through the edge. This succession will also modify the biological responses, such as seedling requirement, browsing, field layer height, and composition (Hamberg et al. 2009; Dovčiak and 
Fig. 5 Heatmap of the UPGMA clustering for the idealized management set. Grouping and dendrogram at the top, abbreviated species to the right (see Table 2), and site numbers at the bottom. The darkest color (red) indicates the highest abundance and the brightest (yellow) the lowest abundance. General growth form of species as small shrub, large shrub, shrub tree/small tree, and tree is graphically illustrated to the left

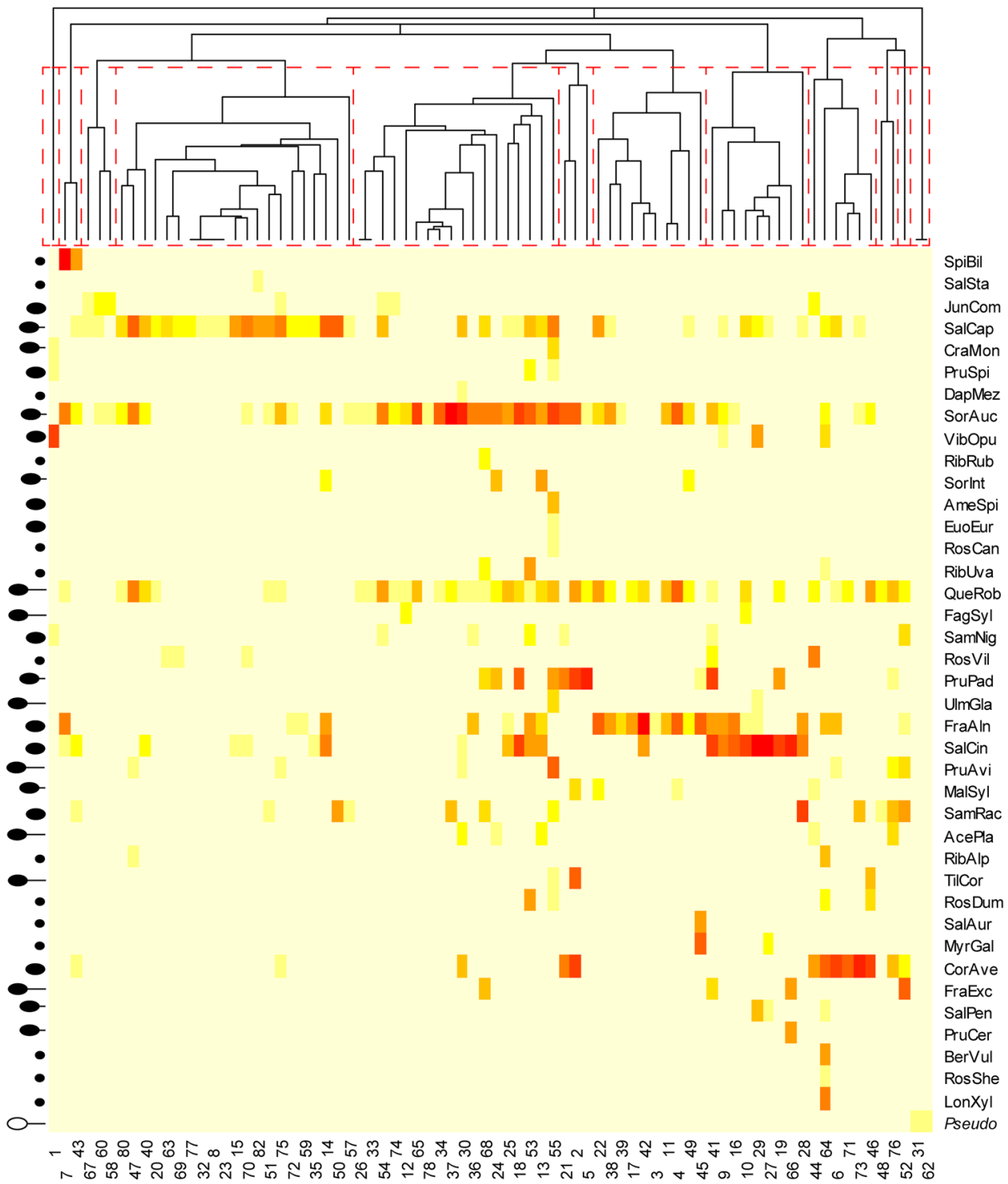

Brown 2014). However, for the successional stage of the edge investigated here, it is clear that the regrowth typologies identified have similar overall vegetation structure, but the magnitude of the structural aspects is clearly linked to site productivity and soil moisture. This indicates that management and regrowth typologies gain adaptability by being related to decisive environmental gradients.

The vegetation structure of the initial regrowth was clearly the opposite of the desired graded profile, in fact being graded in the reverse direction, with increasing height toward the railroad, most likely because of rising light levels with increasing distance from the shading stand trees. This emphasizes the need for structural approaches to forest edge management, as presented by, e.g., Wiström et al. (2015).

\section{Management Implications and Perspectives}

Combining the results for species abundances with the heatmap clusters showed that the broad-leaved pioneer species Populus tremula, Betula pendula, and Betula pubescens dominated the NMC and partly the STAND zone, but with a clear shift toward Pinus sylvestris and Picea abies in the latter. These two species are the most common commercial wood species in Sweden and their dominance in the STAND zone probably reflects commercial forest management practices. Although forestry practices may weaken or reinforce some relationships between species composition and environmental gradients, the actual species composition in the STAND zone will have a strong impact as a seed source on the species composition of the NMC. The vegetative regeneration capacity, i.e., sprouting from 
Fig. 6 Regression tree for the NMC with the five clusters appearing in Table 3 and Fig. 7. Abbreviated (see Table 2) significant indicator species with accompanying indicator values are plotted for split and final clusters. Soil moisture: (a) dry (torrt), (b) slightly dry, (c) damp (friskt), (d) slightly moist, (e) moist (fuktigt), (f) slightly wet, (g) wet (blött), (h) very wet. Field layer type indicating site fertility, where a is the poorest and $i$ the richest site: (a) horsetail-sedge type, (b) crowberry-heather type, (c) lingonberry type, (d) bilberry type, (e) narrow-leaved grass type, (f) broad-leaved grass type, (g) without field layer, (h) low herb type, (i) tall herb type

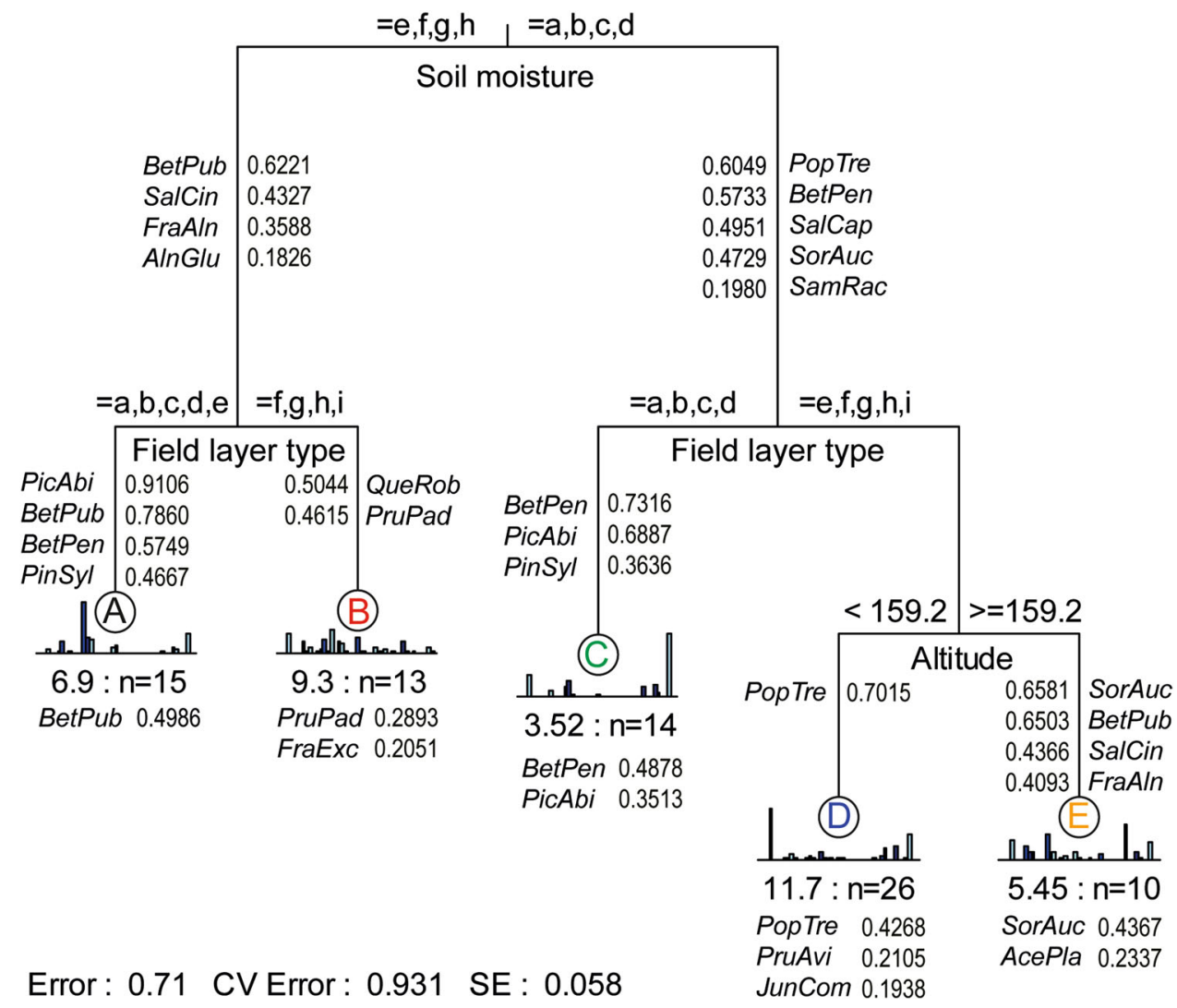

the stool and roots, of Populus tremula and Betula species can also explain their dominance in the early successional stage of the NMC (Del Tredici 2001). Alnus glutinosa also has the ability to sprout from the stool. Its dominance was restricted to moist-wet sites, but when present it clearly dominated in both the NMC and STAND zones.

Controlling the dominance of tree species is a key aspect in the creation of graded forest edges and management of other types of ROW vegetation (Meilleur et al. 1994; Mercier et al. 2001; Wiström and Nielsen 2014; Wiström et al. 2015). In relation to this, reversing the classical precommercial thinning approach used in forestry, where the focus is on promoting (the commercial) species, and instead focusing on the species to be controlled would be a simple way to promote a wide range of suitable species, without the requirement of field staff with specialist taxonomic knowledge, facilitating potential implementation in practice. This selective thinning approach was conceptualized here as Functional Species Control.

Running the clustering with the six dominant tree species (Alnus glutinosa, Betula pendula, Betula pubescens, Picea abies, Pinus sylvestris, and Populus tremula) removed in the idealized data set showed that if these six species are cleared within Functional Species Control, desirable lower tree and shrubs species are generally present so they can form the building blocks for development of a graded edge profile. Based on the findings of Meilleur et al. (1994, 1997), Frappier et al. (2004), Hamberg et al. (2014), and Wiström and Nielsen (2014), the presence of Sorbus aucuparia, Corylus avellana, Salix cinerea, and Frangula alnus in particular can be expected to have the capacity to reduce re-growth of the species targeted by Functional Species Control. However, this needs further investigation, especially in relation to required abundance at different sites and their palatability to browsing. Quercus robur, Salix caprea, and the other less common tree species left by Functional Species Control will be more liberated in the crowns, hopefully leading to more free-growing and windadapted trees (Mason 2002). These species will also support more complex structures (as well as important conservation values; e.g., Kearns et al. 1998) by their height growth. However, for the same reason these tree species need to be monitored to prevent a future risk of wind-felling. The amount of Quercus robur and Salix caprea provides an interesting trade-off in management decisions. Both these species are considered especially valuable for biodiversity in Sweden (e.g., Götmark 2010), but at the same time they pose a possible risk in infrastructure corridors. In Denmark, Quercus robur is the only tree species allowed in management corridors, due to its high wind resistance and high biodiversity value. In Sweden, the attitude among managers seems to be moving toward a similar approach for 
Table 2 Abbreviation and scientific name of species identified in the study

\begin{tabular}{|c|c|c|c|}
\hline Abbreviation & Scientific name & Abbreviation & Scientific name \\
\hline AcePla & Acer platanoides $\mathrm{L}$. & PruSpi & Prunus spinosa $\mathrm{L}$. \\
\hline AcePse & Acer pseudoplatanus L. & QueRob & Quercus robur L. \\
\hline AesHip & Aesculus hippocastanum L. & RhaCat & Rhamnus cathartica L. \\
\hline AlnGlu & Alnus glutinosa (L.) Gaertn. & RibAlp & Ribes alpinum $\mathrm{L}$. \\
\hline AmeSpi & Amelanchier spicata (Lam.) K. Koch & RibNig & Ribes nigrum $\mathrm{L}$. \\
\hline BerVul & Berberis vulgaris $\mathrm{L}$. & RibSpi & Ribes spicatum E. Robson \\
\hline BetPen & Betula pendula Roth & RibUva & Ribes uva-crispa $\mathrm{L}$. \\
\hline BetPub & Betula pubescens Ehrh. & RosCan & Rosa canina $\mathrm{L}$. \\
\hline CarBet & Carpinus betulus L. & RosDum & Rosa dumalis Bechst. \\
\hline CorAve & Corylus avellana $\mathrm{L}$. & RosShe & Rosa sherardii Davies \\
\hline CraLae & Crataegus laevigata (Poir.) DC. & RosVil & Rosa villosa $\mathrm{L}$. \\
\hline DapMez & Daphne mezereum $\mathrm{L}$. & SalAlb & Salix alba $\mathrm{L}$. \\
\hline EuoEur & Euonymus europaeus L. & SalAur & Salix aurita L. \\
\hline FagSyl & Fagus sylvatica L. & SalCap & Salix caprea $\mathrm{L}$. \\
\hline FraAln & Frangula alnus Mill. & SalCin & Salix cinerea $\mathrm{L}$. \\
\hline FraExc & Fraxinus excelsior $\mathrm{L}$. & SalPen & Salix pentandra $\mathrm{L}$. \\
\hline JunCom & Juniperus communis L. & SalSta & Salix starkeana Willd. \\
\hline LonXyl & Lonicera xylosteum L. & SamNig & Sambucus nigra L. \\
\hline MahAqu & Mahonia aquifolium (Pursh) Nutt. & SamRac & Sambucus racemosa $\mathrm{L}$. \\
\hline MalSyl & Malus sylvestris (L.) Mill. & SorAuc & Sorbus aисираria L. \\
\hline MyrGal & Myrica gale $\mathrm{L}$. & SorInt & Sorbus intermedia (Ehrh.) Pers. \\
\hline PicAbi & Picea abies (L.) H. Karst & SpiBil & Spiraea $x$ billardii Hérincq \\
\hline PinSyl & Pinus sylvestris L. & TaxBac & Taxus baccata L. \\
\hline PopTre & Populus tremula $\mathrm{L}$. & TilCor & Tilia cordata Mill. \\
\hline PruAvi & Prunus avium $\mathrm{L}$. & UlmGla & Ulmus glabra Huds. \\
\hline PruPad & Prunus padus L. & VibOpu & Viburnum opulus L. \\
\hline
\end{tabular}

Table 3 Main effects and SLICE effects for the different structural aspects in relation to position across the forest edge section (Plot) and the different regrowth types (Cluster) identified through regression tree analysis, as seen in Fig. 6

\begin{tabular}{|c|c|c|c|c|c|c|c|c|c|c|}
\hline & \multicolumn{2}{|c|}{ Field layer cover } & \multicolumn{2}{|c|}{ Field layer height } & \multicolumn{2}{|c|}{ Maximum height } & \multicolumn{2}{|c|}{ Number of seedlings } & \multicolumn{2}{|c|}{ Number of stems } \\
\hline & $F$-value & $\operatorname{Pr}>F$ & $F$-value & $\operatorname{Pr}>F$ & $F$-value & $\operatorname{Pr}>F$ & $F$-value & $\operatorname{Pr}>F$ & $F$-value & $\operatorname{Pr}>F$ \\
\hline \multicolumn{11}{|l|}{ Main effects } \\
\hline Cluster & 10.66 & $<.0001$ & 22.27 & $<.0001$ & 2.68 & 0.0385 & 6.76 & 0.0001 & 3.83 & 0.0070 \\
\hline Plot & 55.35 & $<.0001$ & 42.86 & $<.0001$ & 10.22 & $<.0001$ & 7.26 & $<.0001$ & 30.75 & $<.0001$ \\
\hline Cluster $\times$ Plot & 2.07 & 0.0097 & 2.43 & 0.0019 & 0.91 & 0.5560 & 2.14 & 0.0070 & 1.74 & 0.0388 \\
\hline \multicolumn{11}{|l|}{ SLICE effects } \\
\hline Plot 1 & 4.10 & 0.0030 & 8.25 & $<.0001$ & 2.32 & 0.0570 & 4.70 & 0.0011 & 3.93 & 0.0040 \\
\hline Plot 2 & 6.77 & $<.0001$ & 13.17 & $<.0001$ & 3.16 & 0.0145 & 7.33 & $<.0001$ & 5.10 & 0.0005 \\
\hline Plot 3 & 10.15 & $<.0001$ & 16.92 & $<.0001$ & 3.02 & 0.0184 & 0.71 & 0.5837 & 3.54 & 0.0077 \\
\hline Plot 4 & 8.07 & $<.0001$ & 18.00 & $<.0001$ & 0.77 & 0.5471 & 3.40 & 0.0097 & 2.16 & 0.0733 \\
\hline Plot 5 & 6.08 & 0.0001 & 13.36 & $<.0001$ & 0.89 & 0.4698 & 2.54 & 0.0398 & 0.83 & 0.5073 \\
\hline \multicolumn{11}{|l|}{ SLICE effects } \\
\hline Cluster A & 10.30 & $<.0001$ & 7.68 & $<.0001$ & 2.50 & 0.0425 & 5.83 & 0.0002 & 5.94 & 0.0001 \\
\hline Cluster B & 5.25 & 0.0004 & 3.18 & 0.0140 & 1.90 & 0.1109 & 0.68 & 0.6051 & 10.01 & $<.0001$ \\
\hline Cluster C & 14.40 & $<.0001$ & 8.02 & $<.0001$ & 1.28 & 0.2778 & 5.56 & 0.0003 & 3.20 & 0.0136 \\
\hline Cluster D & 37.20 & $<.0001$ & 35.69 & $<.0001$ & 5.22 & 0.0004 & 2.28 & 0.0609 & 10.70 & $<.0001$ \\
\hline Cluster E & 9.08 & $<.0001$ & 8.57 & $<.0001$ & 3.88 & 0.0043 & 1.83 & 0.1222 & 8.99 & $<.0001$ \\
\hline
\end{tabular}

Note: As an example of SLICE effects results, for number of seedlings Plot has a significant effect for Clusters A and C, but not for Clusters B, D, and E 
Fig. 7 Structural responses in relation to spatial location and regrowth types (clusters) obtained through regression tree analysis, as seen in Fig. 6. Plot 1 is closest to the railroad, plot 3 on the forest edge border, and plot 5 farthest into the stand. Sqrt indicates square root transformation of the response variable. A diagram showing the pattern of the mean effect for each response is located in the upper right corner of each graph
Number of stems per plot

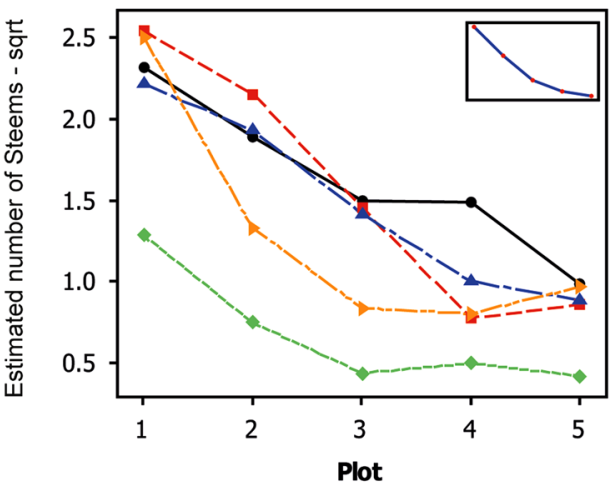

Number of seedlings per plot

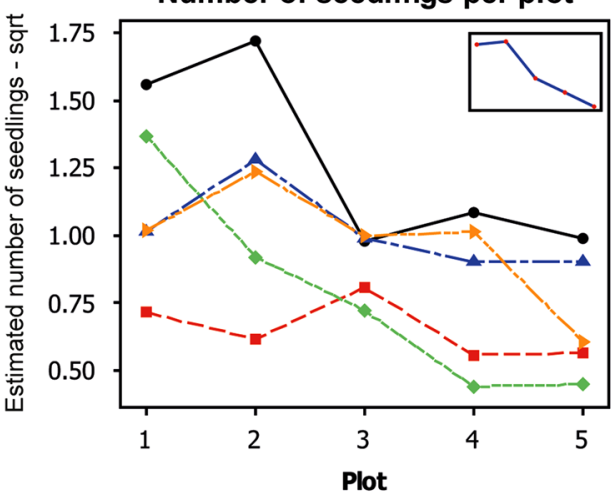

Average field layer height

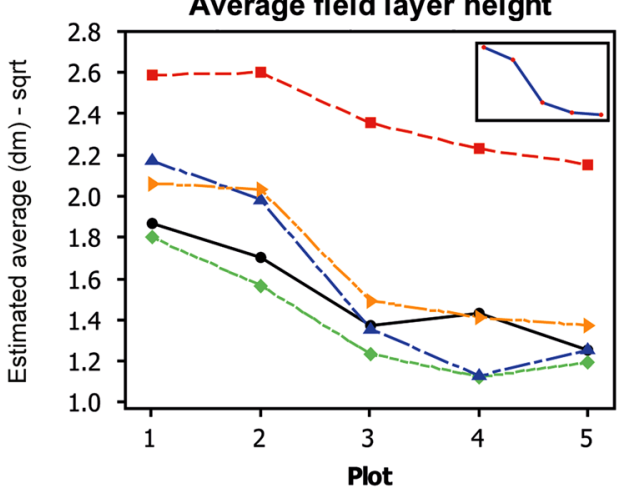

Maxium height of stems

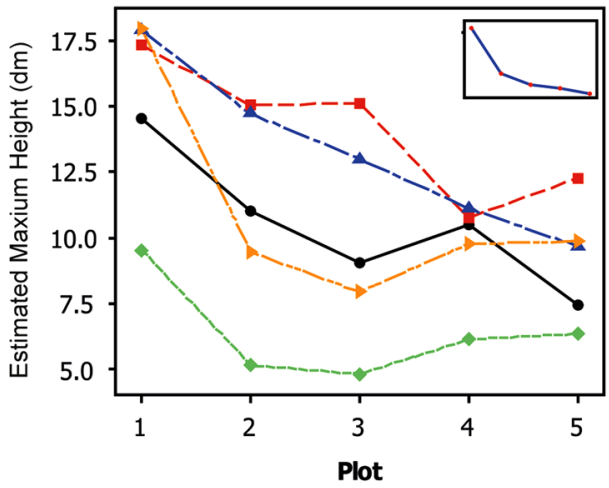

Field layer cover
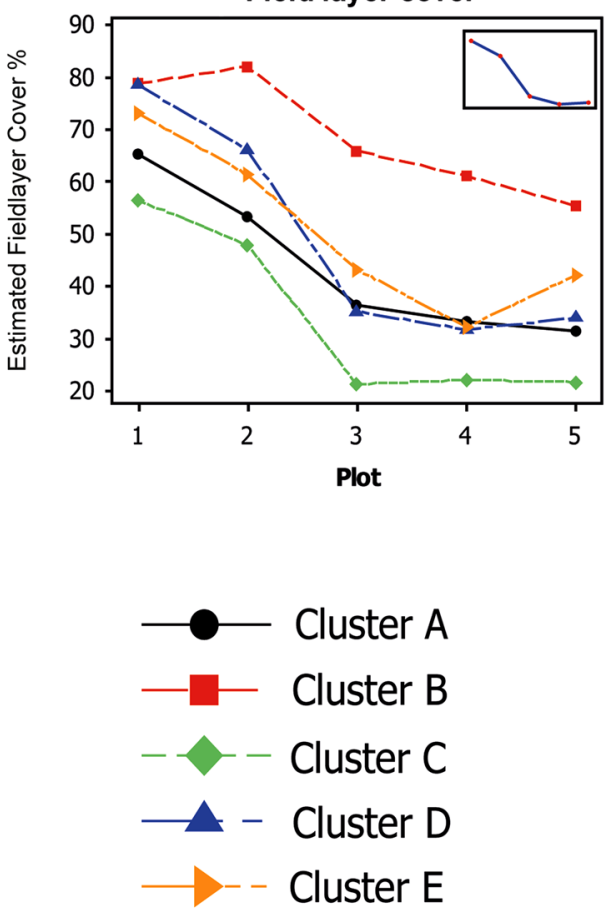

Quercus and other long-lived, broad-leaved trees (personal communication with Danish and Swedish Transport Administrations).

The regression tree and associated indicator species in the present study showed that most of the "building block" species occur and are most abundant at richer field sites (grass-dominated and herb-dominated field layers). Even if the species that are currently subordinate are unable to suppress regrowth of the species targeted by Functional Species Control at poorer sites (Vaccinium and Calluna dwarf shrub types), selective cutting of the six tree species currently dominating will support "lifeboating" (Puettmann and Tappeiner 2014) of building block species and other rare species.
For future testing and further development and adaptation of Functional Species Control as a potential management system for developing woody regrowth along the SML railroad toward a graded edge profile with desirable species composition, a forest edge management trial has recently been implemented (autumn 2014) at 25 of the field sites included in this study. These sites are intended to represent all five clusters identified from the regression tree, with the aim of testing the Functional Species Control approach across the most decisive environmental gradients and related clusters of species. This management trial is named Forest Edge Development Gradient Experiment. 
Acknowledgements This study was funded by the Swedish Transport Administration and we are grateful for their practical support, especially that of Jan-Erik Lundh. We acknowledge help in retrieving and discussing GIS data provided by Maria Andersson Barrdahl and Lars Göran Bertil Andersson. We are thankful to Emma Holmström for fruitful discussions about vegetation sampling, Jan-Eric Englund for statistical advice, and Blaž Klobučar for field assistance in the second stage of the project. We also acknowledge the anonymous referees for their valuable comments and suggestions.

Funding This study was funded by the Swedish Transport Administration, Dnr: F08-6517/AL50 and Dnr 2013.4.1-1208.

Conflict of Interest The authors declare that they have no conflict of interest.

\section{References}

Austin MP, Belbin L, Meyers JA, Doherty MD, Luoto M (2006) Evaluation of statistical models used for predicting plant species distributions: role of artificial data and theory. Ecol Model 199:197-216

Ballard BD, McLoughlin KT, Nowak CA (2007) New diagrams and applications for the wire zone-border zone approach to vegetation management on electric transmission line rights-of-way. Arboric Urban For 33:435-439

Berg Å, Ahrné K, Öckinger E, Svensson R, Wissman J (2013) Butterflies in semi-natural pastures and power-line corridors-effects of flower richness, management, and structural vegetation characteristics. Insect Conserv Diver 6:639-657

Borcard D, Gillet F, Legendre P (2011) Numerical ecology with R. Springer, New York

Buckley GP, Howell R, Watt TA, Ferris-Kaan R, Anderson MA (1997) Vegetation succession following ride edge management in lowland plantations and woods. 1. The influence of site factors and management practices. Biol Conserv 82:289-304

Cáceres MD, Legendre P (2009) Associations between species and groups of sites: indices and statistical inference. Ecology 90:3566-3574

Clarke DJ, White JG (2008) Towards ecological management of Australian powerline corridor vegetation. Landsc Urban Plan $86: 257-266$

Coch T (1995) Waldrandpflege: Grundlagen und Konzepte. Neumann, Radebeul

De'ath G (2002) Multivariate regression trees: a new technique for modeling species-environment relationships. Ecology 83:1105-1117

De'ath G, Fabricius KE (2000) Classification and regression trees: a powerful yet simple technique for ecological data analysis. Ecology 81:3178-3192

Del Tredici P (2001) Sprouting in temperate trees: a morphological and ecological review. Botanical Rev 67:121-140

Didham RK, Lawton JH (1999) Edge structure determines the magnitude of changes in microclimate and vegetation structure in tropical forest fragments. Biotropica 31:17-30

Dovčiak M, Brown J (2014) Secondary edge effects in regenerating forest landscapes: vegetation and microclimate patterns and their implications for management and conservation. New For 45:733-744

Dreyer GD, Niering WA (1986) Evaluation of two herbicide techniques on electric transmission rights-of-way: development of relatively stable shrublands. Environ Manage 10:113-118
Dufrene M, Legendre P (1997) Species assemblages and indicator species: the need for a flexible asymmetrical approach. Ecol Monogr 67:345-366

El-Hamdouchi A, Willett P (1989) Comparison of hierarchic agglomerative clustering methods for document retrieval. Comput J 32:220-227

Ellenberg H (1988) Vegetation ecology of Central Europe. Cambridge University Press, Cambridge

Fankhauser S, Smith JB, Tol RSJ (1999) Weathering climate change: some simple rules to guide adaptation decisions. Ecol Econ 30:67-78

Frappier B, Eckert RT, Lee TD (2004) Experimental removal of the non-indigenous shrub Rhamnus frangula (Glossy Buckthorn): effects on native herbs and woody seedlings. Northeast Nat 11:333-342

Fry G, Sarlöv-Herlin I (1997) The ecological and amenity functions of woodland edges in the agricultural landscape, a basis for design and management. Landsc Urban Plan 37:45-55

Gallegos Torell §̊ (ed) (2011) Fältinstruktion för Nationell Inventering av Landskapet i Sverige, NILS 2011. Institutionen för skoglig resurshushållning. Swedish University of Agricultural Sciences, Umeå

Grashof-Bokdam C (1997) Forest species in an agricultural landscape in the Netherlands: effects of habitat fragmentation. J Veg Sci 8:21-28

Grime JP (2001) Plant strategies, vegetation processes, and ecosystem properties. Wiley, Chichester

Götmark F (2010) Skötsel av skogar med höga naturvärden-en kunskapsöversikt. (Management alternatives for temperate forests with high conservation values in south Sweden). Svensk Bot Tidskr 104:S1-S88

Götzenberger L, de Bello F, Bråthen KA, Davison J, Dubuis A, Guisan A, Lepš J, Lindborg R, Moora M, Pärtel M, Pellissier L, Pottier J, Vittoz P, Zobel K, Zobel M (2012) Ecological assembly rules in plant communities-approaches, patterns and prospects. Biol Rev 87:111-127

Hägglund B, Lundmark JE (2007a) Handledning i bonitering Del 1 Definitioner och anvisningar. Skogstyrelsen, Jönköping

Hägglund B, Lundmark JE (2007b) Handledning i bonitering Del 2 Diagram och tabeller. Skogstyrelsen, Jönköping

Hägglund B, Lundmark JE (2010) Handledning i bonitering Del 3 Markvegetationstyper. Skogsstyrelsen, Jönköping

Hamberg L, Fedrowitz K, Lehvävirta S, Kotze DJ (2010) Vegetation changes at sub-xeric urban forest edges in Finland-the effects of edge aspect and trampling. Urban Ecosyst 13:583-603

Hamberg L, Lehvävirta S, Kotze DJ (2009) Forest edge structure as a shaping factor of understorey vegetation in urban forests in Finland. For Ecol Manag 257:712-722

Hamberg L, Lehvävirta S, Malmivaara-Lämsä M, Rita H, Kotze DJ (2008) The effects of habitat edges and trampling on understorey vegetation in urban forests in Helsinki, Finland. Appl Veg Sci 11:83-98

Hamberg L, Malmivaara-Lämsä M, Löfström I, Hantula J (2014) Effects of a biocontrol agent Chondrostereum purpureum on sprouting of Sorbus aucuparia and Populus tremula after four growing seasons. BioControl 59:125-137

Henriksen HA (1988) Skoven og dens dyrkning. Dansk skovforening, Copenhagen

Hill JD, Canham CD, Wood DM (1995) Patterns and causes of resistance to tree invasion in rights-of-way. Ecol Appl 5: 459-470

IPCC (2013) Climate Change 2013: The Physical Science Basis Contribution of Working Group I to the Fifth Assessment Report of the Intergovernmental Panel on Climate Change. In: Stocker, TF, Qin, D, Plattner, G-K, Tignor, M, Allen, SK, Boschung, J, Nauels, A, Xia, Y, Bex, V and Midgley, PM (eds). Cambridge University Press, Cambridge 
Jansen F, Oksanen J (2013) How to model species responses along ecological gradients-Huisman-Olff-Fresco models revisited. J Veg Sci 24:1108-1117

Kearns CA, Inouye DW, Waser NM (1998) Endangered mutualisms: the conservation of plant-pollinator interactions. Annu Rev Ecol Syst 29:83-112

Knight AT, Cowling RM, Campbell BM (2006) An operational model for implementing conservation action. Conserv Biol 20: 408-419

kNN-Sverige (2010) Institutionen för skoglig resurshushållning, SLU. http://skogskarta.slu.se/

Komonen A, Lensu T, Kotiaho JS (2013) Optimal timing of power line rights-of-ways management for the conservation of butterflies. Insect Conserv Divers 6:522-529

Larsen JB, Nielsen AB (2007) Nature-based forest managementwhere are we going?: elaborating forest development types in and with practice. For Ecol Manag 238:107-117

Legendre P, Legendre L (1998) Numerical ecology. Elsevier, Amsterdam, 2nd English edition

Leviäkangas P, Michaelides S (2014) Transport system management under extreme weather risks: views to project appraisal, asset value protection and risk-aware system management. Nat Hazards 72:263-286

Lindner M, Maroschek M, Netherer S, Kremer A, Barbati A, GarciaGonzalo J, Seidl R, Delzon S, Corona P, Kolström M, Lexer MJ, Marchetti M (2010) Climate change impacts, adaptive capacity, and vulnerability of European forest ecosystems. For Ecol Manag 259:698-709

Luken JO, Hinton AC, Baker DG (1991) Assessement of frequent cutting as a plant-community management technique in powerline corridors. Environ Manag 15:381-388

Lundin L, Karltun E, Odell G, Löfgren O (2002) Fältinstruktion för ståndortskartering av permanenta provytor vid riksskogstaxeringen. SK 2002. Institutionen för skoglig marklära, Swedish University of Agricultural Sciences, Uppsala

Maechler M, Rousseeuw P, Struyf A, Hubert M, Hornik K (2014) Cluster: Cluster Analysis Basics and Extensions. R package version 1.15 .2

Marozas V, Grigaitis V, Brazaitis G (2005) Edge effect on ground vegetation in clear-cut edges of pine-dominated forests. Scand J For Res 20:43-48

Mason WL (2002) Are irregular stands more windfirm? Forestry 75:347-355

McGarigal K, Cushman SA, Ene E (2012) FRAGSTATS v4: Spatial Pattern Analysis Program for Categorical and Continuous Maps. Computer software program produced by the authors at the University of Massachusetts, Amherst. Available at the web site: http://www.umass.edu/landeco/research/fragstats/fragstats.html

Meilleur A, Véronneau H, Bouchard A (1994) Shrub communities as inhibitors of plant succession in southern Quebec. Environ Manag 18:907-921

Meilleur A, Véronneau H, Bouchard A (1997) Shrub propagation techniques for biological control of invading tree species. Environ Manag 21:433-442

Mercier C, Brison J, Bouchard A (2001) Demographic analysis of tree colonization in a 20-year-old right-of-way. Environ Manag 28:777-787

Morelli F, Beim M, Jerzak L, Jones D, Tryjanowski P (2014) Can roads, railways and related structures have positive effects on birds?- a review. Transp Res Part D Transp Environ 30:21-31

Murcia C (1995) Edge effects in fragmented forests: implications for conservation. Trends Ecol Evolut 10:58-62

Non WC, de Vries HH (2013) Succesful forest edge management for butterflies (Lepidoptera). Proceedings of the Netherlands Entomological Society Meeting, Nederlandse Entomologische Vereniging, Amsterdam, 24:35-44
Nowak CA, Ballard BD (2005) A framework for applying integrated vegetation management on rights-of-way. J Arboric 31:28-37

Oksanen J, Guillaume Blanchet F, Kindt R, Legendre P, Minchin PR, O'Hara RB, Simpson GL, Solymos P, Stevens MHH, Wagner H (2013) Vegan: Community Ecology Package. R package version 2.0-9. http://CRAN.R-project.org/package = vegan

Ouellette M-H, Legendre P (2013) MVPARTwrap: Additional features for package mvpart. $\mathrm{R}$ package version 0.1-9.2. http://CRAN.Rproject.org/package $=$ MVPARTwrap

Påhlsson L (1998) Vegetationstyper i Norden TemaNord. Nordiska Ministerrådet, Copenhagen

Peper J, Jansen F, Pietzsch D, Manthey M (2011) Patterns of plant species turnover along grazing gradients. J Veg Sci 22:457-466

Puettmann KJ, Tappeiner JC (2014) Multi-scale assessments highlight silvicultural opportunities to increase species diversity and spatial variability in forests. Forestry $87: 1-10$

R Core Team (2014) R: a language and environment for statistical computing. R Foundation for Statistical Computing, Vienna

Ranney JW, Bruner MC, Levenson JB (1981) The importance of edge in the structure and and dynamics of forest islands. In: Burgess RL, Sharpe DM (eds) Forest islands dynamics in man-dominated landscapes. Springer, New York, NY, p 67-96

Reese H, Nilsson M, Pahlén TG, Hagner O, Joyce S, Tingelöf U, Egberth M, Olsson H (2003) Countrywide estimates of forest variables using satellite data and field data from the national forest inventory. AMBIO 32:542-548

Ries L, Fletcher RJ, Battin J, Sisk TD (2004) Ecological responses to habitat edges: mechanisms, models, and variability explained. Annu Rev Ecol Syst 35:491-522

Roberts DW (2013) labdsv: ordination and multivariate analysis for ecology. R package version 1.6-1. http://CRAN.R-project.org/ package $=$ labdsv

Rousseeuw PJ (1987) Silhouettes: a graphical aid to the interpretation and validation of cluster analysis. J Comput Appl Math 20:53-65

Ruck B, Frank C, Tischmacher M (2012) On the influence of windward edge structure and stand density on the flow characteristics at forest edges. Eur J For Res 131:177-189

Rühle G (1995) Innovative Prozesse bei der Indstandhaltung des Grüns an der Bahn. Eisenbahningenieur 46:588-593

Rydberg D (2000) Initial sprouting, growth and mortality of European aspen and birch after selective coppicing in central Sweden. For Ecol Manag 130:27-35

Rydberg D, Falck J (2000) Urban forestry in Sweden from a silvicultural perspective: a review. Landsc Urban Plan 47:1-18

Šálek L, Zahradník D, Marušák R, Jeřábková L, Merganič J (2013) Forest edges in managed riparian forests in the eastern part of the Czech Republic. For Ecol Manag 305:1-10

Therneau TM, Atkinson B, Ripley B, De'ath G (2013) mvpart: Multivariate partitioning. $\mathrm{R}$ package version $1.6-1$. http://CRAN.Rproject.org/package $=$ mvpart

Turner MG, Gardner RH, O'Neill RV (2001) Landscape ecology in theory and practice. Springer Science, New York

Wagner C (1912) Der Blendersaumschlag und sein System Laupp 'sche. Buchhandlung, Tubingen

Wagner DL, Metzler KJ, Leicht-Young SA, Motzkin G (2014) Vegetation composition along a New England transmission line corridor and its implications for other trophic levels. For Ecol Manag 327:231-239

Whittaker RH (1956) Vegetation of the Great Smoky Mountains. Ecol Monogr 26:1-80

Winer BJ (1971) Statistical principles in experimental design, 2nd edn. McGraw-Hill, New York, NY

Wirth R, Meyer S, Leal I, Tabarelli M (2008) Plant herbivore interactions at the forest edge. In: Lüttge U, Beyschlag W, Murata J (eds) Progress in botany, vol 69. Springer, Berlin Heidelberg, pp 423-448 
Wiström B, Nielsen AB (2014) Effects of planting design on planted seedlings and spontaneous vegetation 16 years after establishment of forest edges. New For 45:97-117

Wiström B, Nielsen AB (2016) Decisive environmental characteristics for woody regrowth in forest edges-patterns along complex environmental gradients in Southern Sweden. For Ecol Manag 363:47-62

Wiström B, Nielsen AB, Klobučar B, Klepec U (2015) Zoned selective coppice- a management system for graded forest edges. Urban For Urban Green 14:156-162
Wuyts K, De Schrijver A, Vermeiren F, Verheyen K (2009) Gradual forest edges can mitigate edge effects on throughfall deposition if their size and shape are well considered. For Ecol Manag 257:679-687

Yahner RH, Yahner RT, Ross BD (2008) Plant species richness on a transmission right-of way in southeastern Pennsylvania, U.S. integrated vegetation management. Arboric Urban For $34: 238-244$ 